Article

\title{
Reclamation of Marine Chitinous Materials for Chitosanase Production via Microbial Conversion by Paenibacillus macerans
}

\author{
Chien Thang Doan ${ }^{1,2} \mathbb{D}^{\circ}$, Thi Ngoc Tran ${ }^{1,2}$, Van Bon Nguyen ${ }^{2}{ }^{-}$, Anh Dzung Nguyen ${ }^{3}$ and \\ San-Lang Wang $1,4, * \mathbb{D}$ \\ 1 Department of Chemistry, Tamkang University, New Taipei City 25137, Taiwan; \\ doanthng@gmail.com (C.T.D.); tranngoctnu@gmail.com (T.N.T.) \\ 2 Department of Science and Technology, Tay Nguyen University, Buon Ma Thuot 630000, Vietnam; \\ bondhtn@gmail.com \\ 3 Institute of Biotechnology and Environment, Tay Nguyen University, Buon Ma Thuot 630000, Vietnam; \\ nadzungtaynguyenuni@yahoo.com.vn \\ 4 Life Science Development Center, Tamkang University, New Taipei City 25137, Taiwan \\ * Correspondence: sabulo@mail.tku.edu.tw; Tel.: +886-2-2621-5656; Fax: +886-2-2620-9924
}

Received: 30 September 2018; Accepted: 31 October 2018; Published: 2 November 2018

\begin{abstract}
Chitinous materials from marine byproducts elicit great interest among biotechnologists for their potential biomedical or agricultural applications. In this study, four kinds of marine chitinous materials (squid pens, shrimp heads, demineralized shrimp shells, and demineralized crab shells) were used to screen the best source for producing chitosanase by Paenibacillus macerans TKU029. Among them, the chitosanase activity was found to be highest in the culture using the medium containing squid pens as the sole carbon/nitrogen $(\mathrm{C} / \mathrm{N})$ source. A chitosanase which showed molecular weights at $63 \mathrm{kDa}$ was isolated from $P$. macerans cultured on a squid pens medium. The purified TKU029 chitosanase exhibited optimum activity at $60{ }^{\circ} \mathrm{C}$ and $\mathrm{pH} 7$, and was stable at temperatures under $50^{\circ} \mathrm{C}$ and $\mathrm{pH}$ 3-8. An analysis by MALDI-TOF MS revealed that the chitosan oligosaccharides (COS) obtained from the hydrolysis of water-soluble chitosan by TKU029 crude enzyme showed various degrees of polymerization (DP), varying from 3-6. The obtained COS enhanced the growth of four lactic acid bacteria strains but exhibited no effect on the growth of $E$. coli. By specialized growth enhancing effects, the COS produced from hydrolyzing water soluble chitosan with TKU029 chitinolytic enzymes could have potential for use in medicine or nutraceuticals.
\end{abstract}

Keywords: chitin; chitosan; protease; chitinase; chitosan oligomers

\section{Introduction}

Chitosan is a polysaccharide consisting of 1,4-ß-linked D-glucosamine residues, partially substituted with $N$-acetyl group. Recently, chitosan oligomer conversion has attracted attention among many researchers, because chitosan oligosaccharides are not only water-soluble, but also show various functional properties such as anti-inflammatory [1], anti-oxidative [2], anti-tumor [1,3], preservative [4], and prebiotic [5,6]. Chitosanase is a useful and environmentally-friendly tool for depolymerizing chitosan into oligosaccharides with various degrees of polymerization (DP). The major sources of chitosanase are bacteria, such as Bacillus, Serratia, Aeromonas, Streptomyces, Pseudomonas, and Paenibacillus. Almost all of these chitinolytic-producing bacteria were reported as using chitin or chitosan as the source of carbon/nitrogen $(\mathrm{C} / \mathrm{N})$. Commercialized chitin and chitosan products are mostly prepared from shrimp shells, crabs shells, or squid pens by chemical treatment to remove the mineral salts and proteins from these fishery processing by-products. In order to save on enzyme 
production cost, and in reutilizing the residual proteins, these chitin and protein-containing raw materials have been reported as the sole $\mathrm{C} / \mathrm{N}$ source for enzyme production by Bacillus [7-10], Pseudomonas [11-13], and Serratia [14,15].

Until now, exopolysaccharides [16-18], $\alpha$-glucosidase inhibitors [19,20], antioxidants [21], and biosurfactants [16] produced by Paenibacillus sp. growing on squid pens, shrimp shells, or crab shells have been reported; however, there have been few reports about chitinase production of Paenibacillus species on these low-cost chitinous materials. In the previous report [22], demineralized crab shells or squid pens have been used as the sole $\mathrm{C} / \mathrm{N}$ source for comparing the activities of chitinase, chitosanases, proteases, and $\alpha$-glucosidase inhibitors by 16 chitinolytic/proteolytic enzymes-producing strains, i.e., Paenibacillus sp. TKU029, Paenibacillus sp. TKU032, Paenibacillus sp. TKU037, Paenibacillus sp. TKU042 [22], Bacillus licheniformis [10], Bacillus cereus [2], Serratia marcescens [15], Serratia ureilytica [14], Pseudomonas aeruginosa [13]. Among these tested strains, Paenibacillus sp. TKU029 together with Paenibacillus sp. TKU042 produced the highest chitosanase activity when squid pens were used as the sole $\mathrm{C} / \mathrm{N}$ source.

In this study, four kinds of the marine byproducts, i.e., squid pen powder (SPP), demineralized crab shell powder (deCSP), demineralized shrimp shell powder (deSSP), and shrimp head powder (SHP), were used as the sole $\mathrm{C} / \mathrm{N}$ source to explore the production of chitosanase by $P$. macerans TKU029 via fermentation. The purification and characterization of these TKU029 chitosanase were performed. The oligomers obtained by hydrolyzing water-soluble chitosan with TKU029 chitosanase were analyzed by MALDI-TOF-MS, and their enhancing effect on the growth of lactic acid bacteria was also estimated.

\section{Results and Discussion}

\subsection{Screening of Chitinous Materials as Sole C/N Source for Chitosanase Production}

Chitinous materials have been proposed as an important factor for producing chitinase/chitosanase by fermentation [22]. Therefore, four containing-chitin marine byproducts (SHP, SPP, deCSP, and deSSP) were investigated for the production of chitinase by P. macerans TKU029 in this study. As shown in Figure 1, the highest chitosanase productivity by P. macerans TKU029 was observed with the $\mathrm{C} / \mathrm{N}$ source of SPP $(0.448 \pm 0.022 \mathrm{U} / \mathrm{mL}, 2$ day). These results were consistent with the research of Doan et al. [22], which showed that Paenibacillus sp. TKU042 produced the highest chitosanase activity on SPP (day 2).

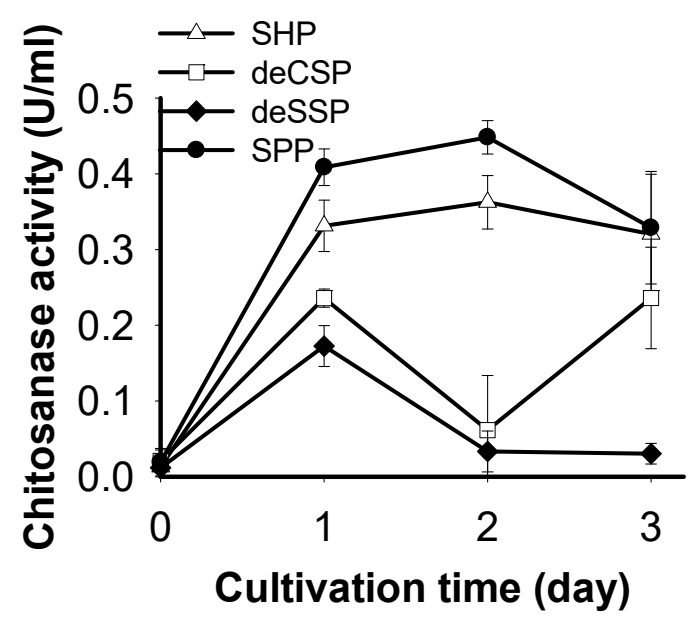

Figure 1. Production of chitosanase by P. macerans TKU029 using different chitin-containing materials as the C/N source. SHP, shrimp head powder; deCSP, demineralized crab shell powder; deSSP, demineralized shrimp shell powder; SPP, squid pen powder. The error bars represent standard deviations $(n=3)$. 
SPP, with its high ratio of protein and low ratio of mineral salts, was claimed to be a good $\mathrm{C} / \mathrm{N}$ source for producing exopolysaccharides and a bio surfactant by P. macerans TKU029 [16]. In this study, SPP was also found to be the best $\mathrm{C} / \mathrm{N}$ source for chitinase production by P. macerans TKU029.

\subsection{Purification and Characterization of Chitosanase}

In order to explore the enzyme characterization and make a comparison with other reports, the chitosanase was purified from the culture supernatant $(600 \mathrm{~mL})$ of P. macerans TKU029 by ethanol precipitation and ion exchange chromatography of DEAE-Sepharose CL-6B. As shown in Figure 2, one chitosanase was eluted with a linear gradient of $0-1 \mathrm{M} \mathrm{NaCl}$ in the same buffer. The eluted fractions of chitosanasewas pooled for further purification by chromatography of Macro-Prep DEAE, respectively. Table 1 summarize the purification results of TKU029 chitosanase, respectively. TKU 029 chitosanase was purified from the culture supernatant with the weight recovery $1.43 \mathrm{mg}$, respectively. The final specific activity and recovery yields of TKU029 chitosanase were $24.19 \mathrm{U} / \mathrm{mg}$ and $10.51 \%$, respectively (Table 1).

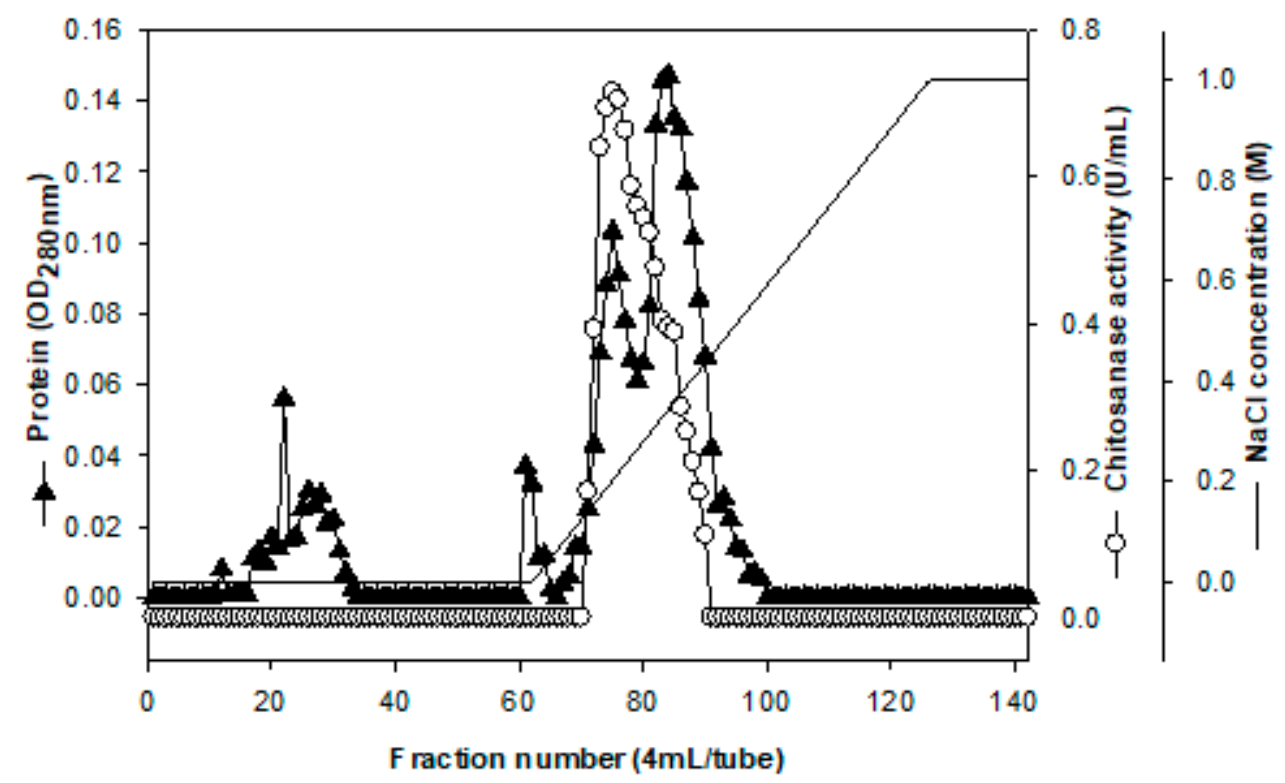

Figure 2. A typical elution profile of chitosanase on DEAE-Sepharose CL-6B column. The column was equilibrated with $50 \mathrm{mM}$ phosphate buffer $(\mathrm{pH} 7)$ at a flow rate of $3 \mathrm{~mL} / \mathrm{min}$ and $4 \mathrm{~mL} /$ fraction.

Table 1. Purification of the chitosanase from P. macerans TKU029.

\begin{tabular}{cccccc}
\hline Step & $\begin{array}{c}\text { Total } \\
\text { Protein }(\mathbf{m g})\end{array}$ & $\begin{array}{c}\text { Total } \\
\text { Activity (U) }\end{array}$ & $\begin{array}{c}\text { Specific } \\
\text { Activity (U/mg) }\end{array}$ & $\begin{array}{c}\text { Recovery } \\
\text { (\%) }\end{array}$ & $\begin{array}{c}\text { Purification } \\
\text { (Fold) }\end{array}$ \\
\hline Culture supernatant & 1245.88 & 328.09 & 0.26 & 100.00 & 1.00 \\
EtOH precipitation & 60.31 & 83.90 & 1.39 & 25.57 & 5.28 \\
DEAE-Sepharose CL-6B & 10.45 & 63.17 & 6.04 & 19.25 & 22.95 \\
Macro-Prep DEAE & 1.43 & 34.48 & 24.19 & 10.51 & 91.87 \\
\hline
\end{tabular}

Similar to most of the other chitinolytic enzymes-producing strains of Paenibacillus species, only one chitinase or chitosanase were purified from the culture supernatant [22-33]. However, the molecular mass of TKU029 chitosanase (63 kDa) estimated by SDS-PAGE (Figure 3) differed from the chitinases or chitosanases of the other Paenibacillus strains, for instance, P. pasadenensis NCIM5434 chitinase (35 kDa) [23], Paenibacillus sp. 1794 chitosanase (40 kDa) [24], P. thermoaerophilus TC22-2b chitinase (48 kDa) [25], P. larvae ATCC9545 (49 kDa) [26], P. illinoisensis KJA-424 chitinase (54 kDa) [33], Paenibacillus sp. D1 chitinase (56 kDa) [27], P. barengoltzii CAU904 chitinase (67 kDa) [28], P. elgii HOA73 chitinase (68 kDa) [29], P. pasadenensis CS0611 
chitinase (69 kDa) [30], Paenibacillus sp. TKU042 chitosanase (70 kDa) [22], Paenibacillus sp. D2 chitosanase (85 kDa) [31], and Paenibacillus sp. FPU-7 (150 kDa) [32].

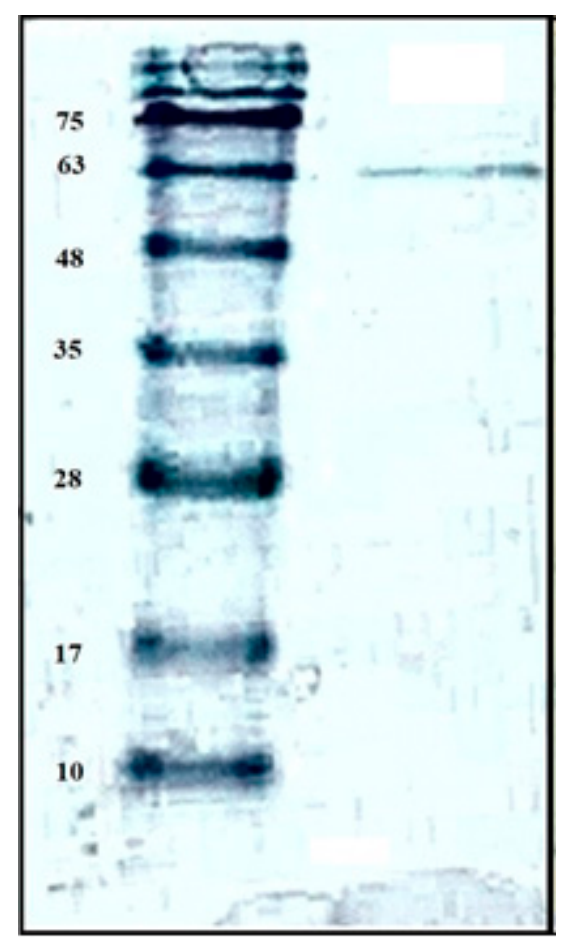

Figure 3. SDS-PAGE analysis of the chitosanase produced by TKU029.

Chitinolytic enzyme productions from Paenibacillus strains on a colloidal-containing chitin medium have been widely reported [23,25,27,33], but rarely on a containing-SPP medium [22]. By using squid pen, a marine byproduct, as the $\mathrm{C} / \mathrm{N}$ source for microbial cultivation, the production cost of microbial chitosanase could be reduced. In this study, a chitosanase from P. macerans TKU029 were isolated by SPP conversion. To the best of our knowledge, this is the first report about chitosanase production from $P$. macerans species using the medium containing SPP.

\subsection{Effects of $\mathrm{pH}$ and Temperature on Activity and Stability of Chitosanase}

The effect of $\mathrm{pH}$ on the activities of TKU029 chitosanase was studied herein (Figure 4). The optimum $\mathrm{pH}$ for TKU029 chitosanase was $\mathrm{pH}$ 7. Compared to chitinase/chitosanase from other Paenibacillus strains, the optimum $\mathrm{pH}$ of TKU029 chitinase differed from most reports, which showed enzyme optimum activity on acid condition; for instance, Paenibacillus sp. D1 [27], P. pasadenensis CS0611 [30], and P. illinoisensis KJA-424 [33] were $\mathrm{pH}$ 5; Paenibacillus sp. 1794 was $\mathrm{pH} 4.8$ [24]; P. barengoltzii was $\mathrm{pH} 3.5$ [28]; P. thermoaerophilus TC22-2b was pH 4 [25]; and Paenibacillus sp. M4 was $\mathrm{pH} 6.5$, but it was consistent with P. elgii HOA73 (pH 7) [29]. These results also observed TKU029 chitosanase to have broad $\mathrm{pH}$ stability ( $\mathrm{pH} 3-8$ ). Several Paenibacillus strains chitinases/chitosanases have broad $\mathrm{pH}$ stability close to that of TKU029 [28,29,34]. 


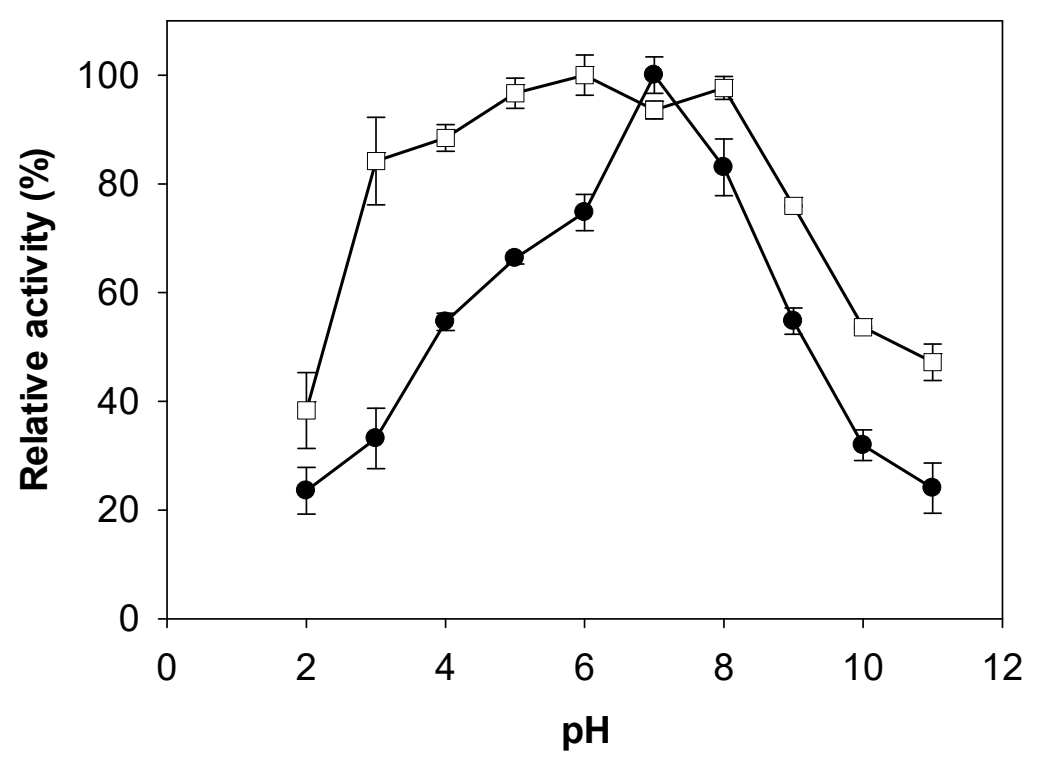

Figure 4. Effect of $\mathrm{pH}$ on activity and stability of TKU029 chitosanase. (๑), enzyme activity; ( $\square)$, enzyme stability. The error bars represent standard deviations $(n=3)$.

The optimum temperature and thermal stability of TKU 029 chitosanasewere also investigated (Figure 5). The optimum temperature of TKU029 chitosanase was $60^{\circ} \mathrm{C}$; it remained stable up to $50{ }^{\circ} \mathrm{C}$. At the optimum temperature of $60^{\circ} \mathrm{C}$, the chitosanase still retained $76 \%$ activity. However, the activity was dramatically decreased to less than half of the highest activity when the temperature was above $60^{\circ} \mathrm{C}$. Generally, the optimum temperature of TKU029 chitosanase is higher than those of other Paenibacillus strains, such as P. pasadenensis NCIM 5434 [23], Paenibacillus sp. D1 [27], P. elgii HOA73 [29], P. pasadenensis CS0611 [30]. Due to the higher optimum temperature, it is suggested that TKU029 chitosanase may be suitable for industrial application.

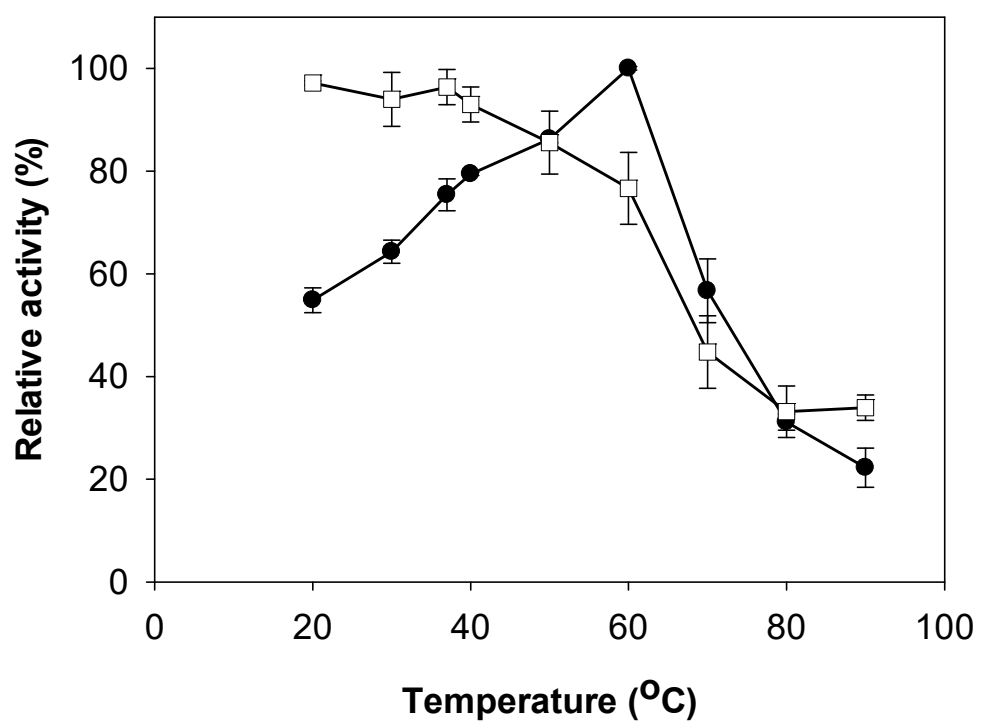

Figure 5. Effect of temperature on activity and stability of TKU029 chitosanase. (•), enzyme activity; $(\square)$, enzyme stability. The error bars represent standard deviations $(n=3)$.

\subsection{Effect of Metal Ions on Activity of Chitosanase}

To further explore the effect of some ion metals on their activities, TKU029 chitosanase were prepared in $50 \mathrm{mM}$ phosphate buffer $(\mathrm{pH} 7)$ containing $5 \mathrm{mM}$ of each chemical and incubated at $37^{\circ} \mathrm{C}$ in $10 \mathrm{~min}$. The mixtures were then examined for their residual activities. The results are summarized in 
Table 2. TKU029 chitosanase activity was not affected by $\mathrm{Zn}^{2+}$ and $\mathrm{Ca}^{2+}$, but other chemicals had clear effects on the enzyme. In the presence of $\mathrm{Cu}^{2+}, \mathrm{Mg}^{2+}, \mathrm{Ba}^{2+}$ and EDTA, the activity of TKU029 chitinase was dramatically reduced with $63.42 \%, 64.31 \%, 76.99 \%$, and $68.10 \%$ residue activity. Interestingly, these results also showed that the addition of $5 \mathrm{mM} \mathrm{Na}^{+}$and $\mathrm{Fe}^{2+}$ into the enzyme solution could enhance chitinase activity (154.22\% and $133.23 \%)$. Similarly, Meena et al. [34], also observed the increased activity with $\mathrm{Fe}^{2+}$ and $\mathrm{Na}^{+}$in Paenibacillus sp. BRSR-047 chitinase.

Table 2. Effect of metal ions on the activity of chitosanase.

\begin{tabular}{cc}
\hline & Relative Activity (\%) \\
\hline Control & $100.00 \pm 1.39$ \\
$\mathrm{Cu}^{2+}$ & $63.42 \pm 1.51$ \\
$\mathrm{Zn}^{2+}$ & $99.75 \pm 1.84$ \\
$\mathrm{Mg}^{2+}$ & $64.31 \pm 2.09$ \\
$\mathrm{Na}^{+}$ & $154.22 \pm 1.96$ \\
$\mathrm{Ba}^{2+}$ & $76.99 \pm 2.03$ \\
$\mathrm{Ca}^{2+}$ & $108.81 \pm 4.13$ \\
$\mathrm{Fe}^{2+}$ & $133.23 \pm 5.31$ \\
EDTA & $68.10 \pm 0.39$ \\
\hline
\end{tabular}

All data points were means \pm standard deviations $(n=3)$.

\subsection{Substrate Specificity of Chitosanase}

The substrate specificity of TKU029 chitosanase was also investigated. As shown in Table 3, TKU029 chitosanase exhibited the most activity on water soluble chitosan, followed by chitosan, colloidal chitin and $\beta$-chitin, but with no activity on the $\alpha$-chitin and non-chitin substrates. These results indicated that the rate of hydrolysis was strongly affected by the physical form of the substrate. In addition, since the enzyme expressed no activity on $p$-nitrophenyl- $N$-acetyl- $\beta$-D-glucosaminide $(p N P G)$, a substrate used for analyzing exochitinase, TKU029 chitosanase could be initially classified as a endochitosanase.

Table 3. Substrate specificity of TKU029 chitosanase.

\begin{tabular}{cc}
\hline Substrate & Relative Activity (\%) \\
\hline Chitosan & $100 \pm 16.93$ \\
Water soluble chitosan & $196.43 \pm 15.55$ \\
$\alpha$-Chitin & 0 \\
$\beta$-Chitin & $12.30 \pm 6.62$ \\
Colloidal Chitin & $63.26 \pm 4.08$ \\
$p$ NPG & 0 \\
Cellulose & 0 \\
Dextran & 0 \\
Starch & 0 \\
\hline
\end{tabular}

All data points were means \pm standard deviations $(n=3)$.

\subsection{Chitosan Hydrolysis and COS Production}

Since water soluble chitosan showed the most effect on TKU029 chitosanase activity, the hydrolysis products from this substrate were also studied. The course of chitosan sample degradation was conveniently studied by the measurement reducing sugar. Figure 6 shows the reducing sugar of the sample as a function of reaction time. The reducing sugar dramatically increased in the early stage of the reaction (after $1 \mathrm{~h}$ of reaction) and did not increase after $4 \mathrm{~h}$. 


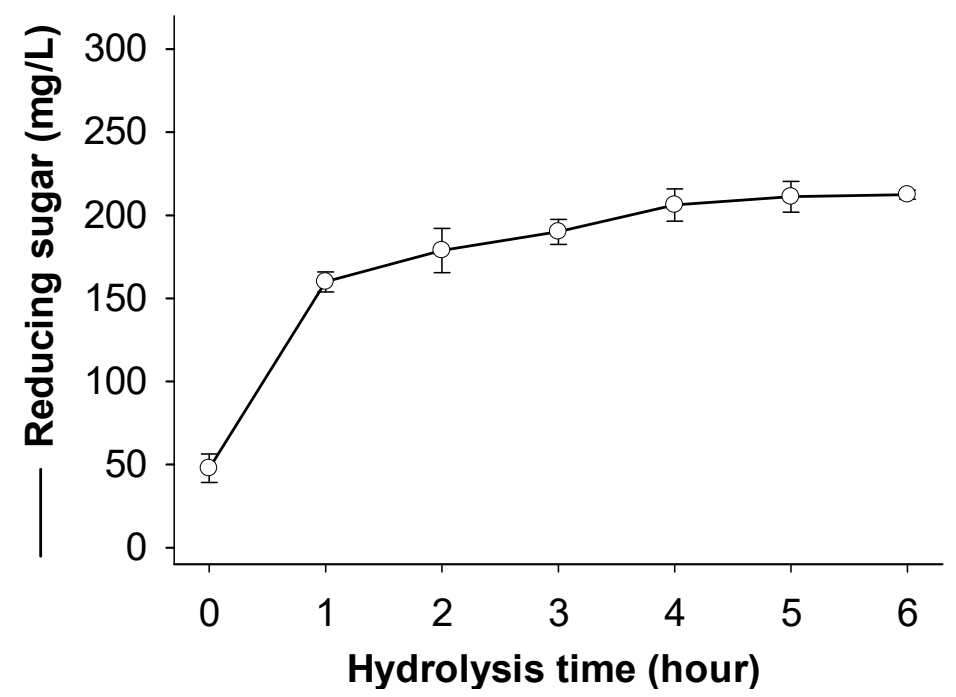

Figure 6. Hydrolysis time course measurement of reducing sugar with TKU029 chitosanase. The reaction mixture in a $250 \mathrm{~mL}$ Erlenmeyer flask containing 1\% water soluble chitosan in $100 \mathrm{~mL}$

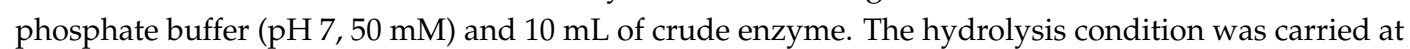
$50{ }^{\circ} \mathrm{C}$ in $6 \mathrm{~h}$. The hydrolysis solution was then tested reducing sugar under the assay mentioned in the methods section. The error bars represent standard deviations $(n=3)$.

COS with low DP have been reported to exhibit several interesting bioactivities, for instance, antioxidant [2], antitumor [1,3], and prebiotic [5,6]. Thus, many studies have recently attracted interest for converting chitosan into chitooligosaccharides. Based on the obtained results, the chitosan hydrolysis by TKU029 crude enzyme was observed to possess great potential to produce chitosan oligosaccharide with low DP.

To obtain the low DP oligomers in the chitosan hydrolysis, selective precipitation in $90 \%$ methanol and acetone solutions was performed following the aforementioned method [2]. Since MALDI-TOF-MS analysis is limited to molecular masses higher than $500 \mathrm{Da}$, the DP $<2$ oligomer could not be determined by this method. The product from the reaction with TKU029 crude enzyme is a mixture containing both homo-chitooligosaccharides, including (GlcN) ${ }_{4}$ (Short form: $\left.\mathrm{G}_{4}\right)(\mathrm{m} / z \mathrm{z} 20,701$ ), $\mathrm{G}_{5}\left(m / z\right.$ 846), $\mathrm{G}_{6}(\mathrm{~m} / z \text { 927, 1040), (GlcNAc) })_{4}$ (Short form: $\left.\mathrm{A}_{4}\right)\left(m / z\right.$ 814), $\mathrm{A}_{5}(m / z 1072)$ and herero-chitooligosacharides, including $\mathrm{G}_{2} \mathrm{~A}_{1}(m / z 536,566), \mathrm{G}_{2} \mathrm{~A}_{2}(m / z 733), \mathrm{G}_{4} \mathrm{~A}_{1}(m / z$ 905, 959), $\mathrm{G}_{2} \mathrm{~A}_{4}(\mathrm{~m} / z$ 1153) (Figure 7). Compared to other reports, COS with different broad DP had been produced by various microoganism strains, for instance, B. cereus TKU027 (DP 4-9, 2-5) [35], B. cereus TKU031 (DP 3-8) [9], Penicillium janthinellum D4 (DP 3-9) [36], Aspergillus fumigatus S-26 (DP 2-7) [33], and Bacillus sp. KFB-C108 (DP 3-5) [37], while this study observed the DP up to 6 and it was only similar to B. cereus TKU022 (DP 2-6) [38]. On the other hand, differing chitosan hydrolysates from other Bacillus strains $[9,35,38]$, the originally-classified genus of Paenibacillus, the hydrolysis products by TKU029 also contained homo-chitosaccharides with higher ratio than hetero-chitosaccharides (at the same DP) (Figure 7). These results indicated that TKU029 chitosanase may hydrolyze the water soluble chitosan by cleavage of glycosidic bonds of the type -G I A- and-A I G-, whereas the hyrolysis of -G I G- and -A I A- are slow. From these results, a quick and simple method to obtain chitosan oligosaccharide with low DP (3-6) could be performed by combining the TKU029 chitosanase hydrolysis reaction with water soluble chitosan at substrate and a selective methanol/acetone precipitation. 


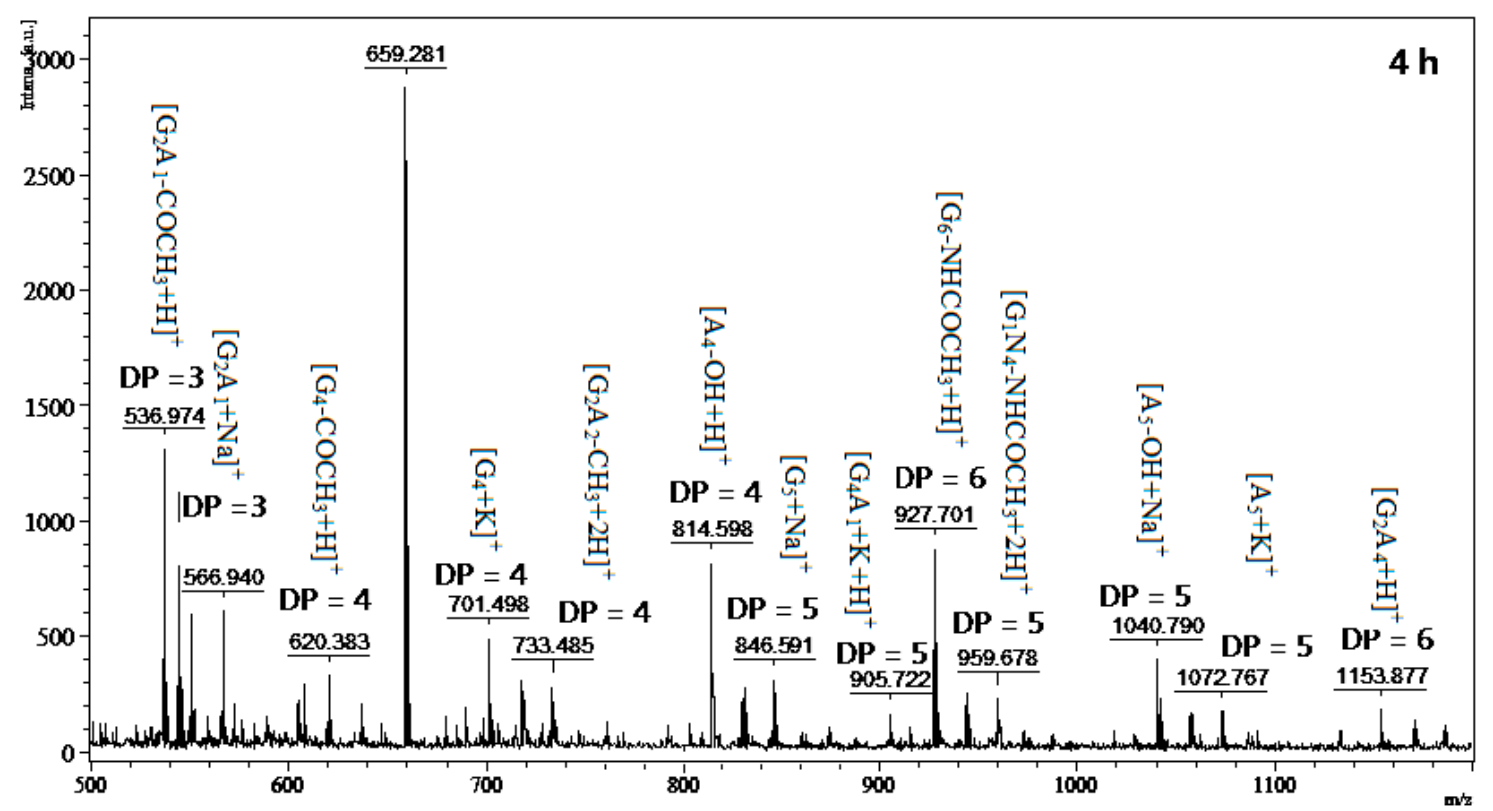

Figure 7. MALDI-TOF-MS of the oligomer mixtures obtained during water soluble chitosan hydrolysis. The proportion of low DP oligomer (DP $<7$ ) was reduced by precipitation in the $90 \%$ methanol-soluble/90\% acetone-insoluble fraction. The identified peaks are labeled with DP, in which DP indicates the degree of polymerization.

\subsection{Evaluation of Growth Enhancing Effect of COS on Lactic Acid Bacteria}

The effect of the chitosan oligosaccharides obtained from chitosan hydrolysis generated by TKU029 chitosanase on the growth of lactic acid bacteria were also studied. As shown in Figure 8, chitosan oligosaccharides, which were collected from different hydrolysis times, have a clear effect on the growth of lactic acid bacteria. The highest cell growth of L. lactis BCRC 10791 was found for the addition of 4-h hydrolyzed chitosan (136.59\%), L. paracasei BCRC 14023 was $2 \mathrm{~h}(169.37 \%)$, L. rhamnosus BCRC 16,000 was $4 \mathrm{~h}$ (164.81\%) and L. rhamnosus BCRC 10791 was $3 \mathrm{~h}$ (153.34\%). Interestingly, adding $0.1 \%$ chitosan oligosaccharides into the medium did not increase the growth of $E$. coli BCRC 51950. These results differed to COS from other reports, which only showed the enhancing effect on lactic acid bacteria $[5,6]$. Due to a prebiotic requiring a selectivity effect on the growth of a limited group of bacteria, it is suggested that COS produced from TKU029 may have the potential to become a prebiotic candidate.

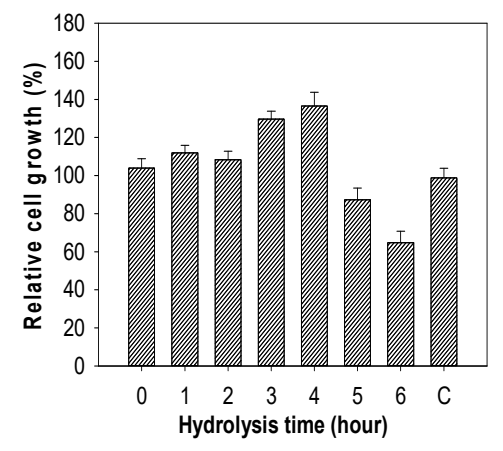

(a)

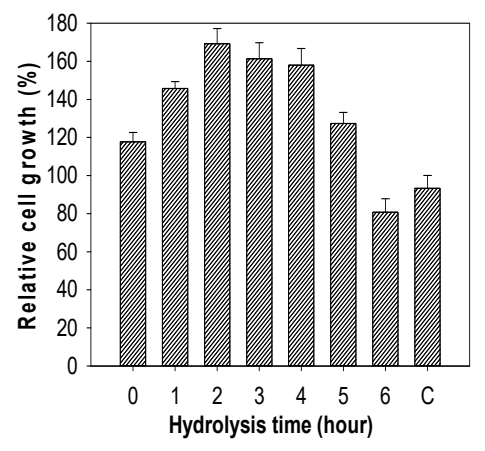

(b)

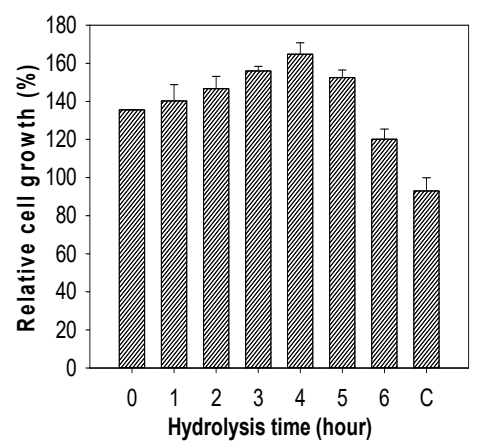

(c)

Figure 8. Cont. 


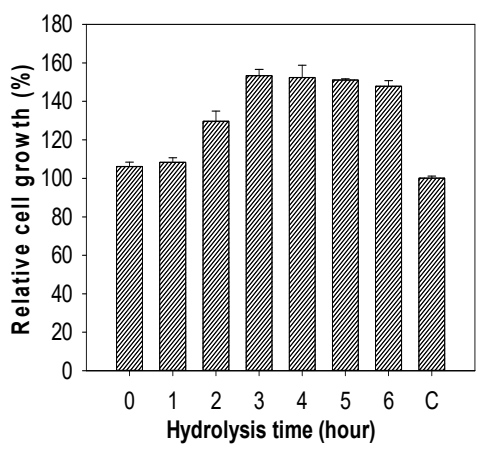

(d)

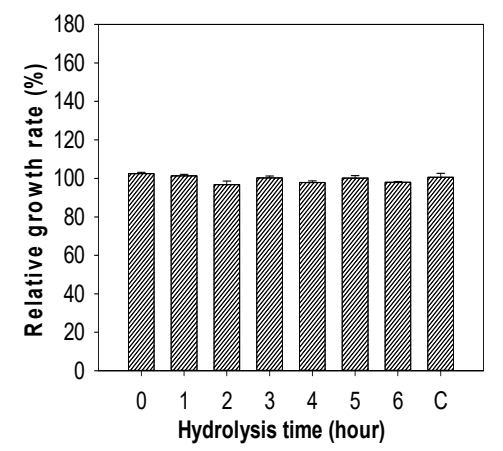

(e)

Figure 8. Effect of the chitosan hydrolysis on the growth of bacteria. (a), L. lactis BCRC 10791; (b), L. paracasei BCRC 14023; (c), L. rhamnosus BCRC 16000; (d), L. rhamnosus BCRC 10791; (e), E. coli BCRC 51,950. The error bars represent standard deviations $(n=3)$.

\section{Materials and Methods}

\subsection{Materials}

Squid pens, crab shells, and shrimp shells were collected from Shin-Ma Frozen Food Co. (I-Lan, Taiwan). Shrimp head powder (SHP) was gifted from Fwu-Sow Industry (Taichun, Taiwan). Demineralized shrimp shell powder (deSSP) and demineralized crab shell powder (deCSP) were prepared via acid treatment [22]. Chitin (from shrimp shell), tyrosine, D-glucosamine and the reagents (3,5-dinitrosalicylic acid and Folin-Ciocalteu) were all purchased from Sigma-Aldrich Corp. (Singapore). Macro-prep DEAE and Macro-Prep High S were bought from Bio-Rad (Hercules, CA, USA). All other reagents were the highest grade available. P. macerans TKU029 [16] was provided by Life Science Development Center, Tamkang University, Taiwan.

\subsection{Measurement of Chitosanase Activity}

The measurement of chitinase activity was performed according to a previously-described method [22], with modifications. Chitosan ( $1 \%$ in $50 \mathrm{mM}$ phosphate buffer) was used as the substrate. The reaction was performed with $0.1 \mathrm{~mL}$ substrate and $0.1 \mathrm{~mL}$ enzyme solution, and kept at $37^{\circ} \mathrm{C}$ for $30 \mathrm{~min}$. The amount of reducing sugar produced in the supernatant was determined by DNS reagent, with D-glucosamine as the reference compound. One unit of enzyme activity was defined as the amount of enzyme that produced $1 \mu \mathrm{mol}$ of reducing sugar per min.

\subsection{Screening of Chitinous Materials as Sole C/N Source for Enzyme Activity}

Four kinds of chitinous materials, i.e., crab shell powder (deCSP), squid pen powder (SPP), shrimp head powder (SHP), and demineralized shrimp shell powder (deSSP), were used as the sole sources of C/N $(1 \%, w / v)$. Paenibacillus macerans TKU029 was grown in $100 \mathrm{~mL}$ of liquid medium in $250 \mathrm{~mL}$ Erlenmeyer flasks containing $1 \%$ of each chitinous material, $0.1 \% \mathrm{~K}_{2} \mathrm{HPO}_{4}$ and $0.05 \% \mathrm{MgSO}_{4} \cdot 7 \mathrm{H}_{2} \mathrm{O}$. The incubation was performed with $1 \%$ of seed culture, in $3 \mathrm{~d}$ at $37^{\circ} \mathrm{C}$ in a shaking incubator $(150 \mathrm{rpm})$. During each of $24 \mathrm{~h}$, the culture medium was collected for further measurements.

\subsection{Purification of Chitosanae}

P. macerans TKU029 was cultured in $100 \mathrm{~mL}$ of liquid medium in an Erlenmeyer flask ( $250 \mathrm{~mL})$ containing $1 \% \mathrm{SPP}, 0.1 \% \mathrm{~K}_{2} \mathrm{HPO}_{4}$ and $0.05 \% \mathrm{MgSO}_{4} .7 \mathrm{H}_{2} \mathrm{O}$ in a shaking incubator for 3 days at $37{ }^{\circ} \mathrm{C}$ to collect culture supernatant. A protein precipitation step was performed by adding $1800 \mathrm{~mL}$ of cold ethanol $\left(-20^{\circ} \mathrm{C}\right)$ to $600 \mathrm{~mL}$ of culture supernatant and kept at $4{ }^{\circ} \mathrm{C}$ overnight. To collect the crude enzyme, the precipitate was centrifuged at $12,000 \times \mathrm{g}$ for $30 \mathrm{~min}$ and then dissolved in a small amount of $50 \mathrm{mM}$ phosphate buffer ( $\mathrm{pH}$ 7). The obtained crude enzyme was loaded onto a DEAE-Sepharose 
CL-6B column that had been equilibrated with $50 \mathrm{mM}$ phosphate buffer. The obtained chitosanase (eluted by a linear gradient of $0-1 \mathrm{M} \mathrm{NaCl}$ in the same buffer) fractions were then further purified by $\mathrm{A}$ Macro-Prep DEAE column, respectively. The molecular mass of the purified enzymes was determined using the SDS-PAGE methods.

\subsection{Effects of $\mathrm{pH}$ and Temperature on Activity and Stability of Chitosanase}

The optimal temperature for the enzymatic reaction was performed at different points of temperature $\left(20-100{ }^{\circ} \mathrm{C}\right)$ during $30 \mathrm{~min}$. To assess the thermal stability, the enzyme solution was treated at a range of temperature during $15 \mathrm{~min}$. The treated enzyme was then used to measure the residual activity.

The optimal $\mathrm{pH}$ of enzyme was measured in buffers of different $\mathrm{pH}$ values $(\mathrm{pH} 2-11)$. To determine the effect of $\mathrm{pH}$ on enzyme stability, the enzyme was incubated in buffer of different $\mathrm{pH}$ levels at $37^{\circ} \mathrm{C}$ for $30 \mathrm{~min}$, and the residual activity was measured at optimal $\mathrm{pH}$ value. The buffer systems used included glycine. $\mathrm{HCl}(50 \mathrm{mM}, \mathrm{pH} 2-3)$, acetate $(50 \mathrm{mM}, \mathrm{pH} 4-5)$, phosphate (50 mM, pH 6-8) and $\mathrm{Na}_{2} \mathrm{CO}_{3}-\mathrm{NaHCO}_{3}(50 \mathrm{mM}, \mathrm{pH}$ 9-11).

\subsection{Effect of Metal Ions on Chitosanase Activity}

Several metal ion salts ( $5 \mathrm{mM}$ in final concentration) were used to investigate their effect on enzyme activity, i.e., $\mathrm{CuCl}_{2}, \mathrm{ZnCl}_{2}, \mathrm{MgCl}_{2}, \mathrm{NaCl}, \mathrm{BaCl}_{2}, \mathrm{CaCl}_{2}, \mathrm{FeCl}_{2}$, and EDTA.

\subsection{Substrate Specificity}

Chitosanase was incubated in $50 \mathrm{mM}$ phosphate buffer with various kinds of substrates at $60^{\circ} \mathrm{C}$ for $30 \mathrm{~min}$. $\alpha$-chitin (from shrimp shell), $\beta$-chitin (from squid pen), chitosan (DD $=65.36 \%$ and $\mathrm{MW}=350,000-500,000 \mathrm{Da})$, water soluble chitosan $(\mathrm{DD}=66.66 \%$ and $\mathrm{MW}=30,000 \mathrm{Da})$, colloidal chitin (from $\alpha$-chitin), cellulose, dextran $(70,000 \mathrm{Da})$, Starch (from potato) were included. The chitinase activity in colloidal chitin was used as a control to calculate the relative activity of enzyme in other substrates.

\subsection{MALDI-TOF MS Analysis}

A sample $(1 \mu \mathrm{L})$ was prepared with $1 \mu \mathrm{L}$ of 2,5-dihydroxybenzoic acid as a matrix in $\mathrm{H}_{2} \mathrm{O}-\mathrm{CAN}-\mathrm{TFA}$ solution $(50 / 50 / 0.1 \%, v / v / v)$. Positive ion mode of MALDI mass spectra was acquired with a MALDI-TOF instrument (Bruker Daltonics, Bremen, Germany) equipped with a nitrogen laser emitting at $337 \mathrm{~nm}$ operating in linear mode. Each mass spectrum was the accumulated data of approximately 30-50 laser shots. External 3-point calibration was used for mass assignment.

\subsection{Growth Enhancing Effect of COS on Lactic Acid Bacteria Test}

Four lactic acid strains were chosen for the experiment: Lactobacillus lactis BCRC 10791, Lactobacillus paracasei BCRC 14023, Lactobacillus rhamnosus BCRC 16,000, and Lactobacillus rhamnosus BCRC 10,791. The bacteria were cultured in MRS medium containing $0.1 \%(w / v)$ chitosan oligosaccharides for $24 \mathrm{~h}$ at $37^{\circ} \mathrm{C}$. To examine whether chitosan oligosaccharides could affect non-lactic acid bacteria, a strain of E. coli BCRC 51,950 was also cultured in LB medium containing $0.1 \%(w / v)$ chitosan oligosaccharides under the same condition with lactic acid bacteria. A measurement of optical density $600 \mathrm{~nm}$ of culture supernatant was used to calculate the cell growth of the bacteria.

\section{Conclusions}

Among the four marine chitinous materials, Paenibacillus macerans TKU029 achieved the best result for chitosanase production using squid pens as the sole carbon/nitrogen source. The molecular weight of the purified TKU029 chitosanase $(63 \mathrm{kDa})$ was different from those of the other Paenibacillus strains. The oligomers obtained by hydrolyzing water soluble chitosan with TKU029 chitosanase possessed specifically enhancing effects on the growth of analyzed four lactic acid bacteria, and had no 
effect on E. coli. By the selective growth enhancing effect of COS, TKU029 chitosanase has potential to be used in the production of nutraceuticals.

Author Contributions: Conceptualization, S.-L.W. and C.T.D.; Methodology, C.T.D. and T.N.T.; Software, C.-T.D.; Validation, S.-L.W. and C.T.D.; Formal Analysis, C.T.D., T.N.T., V.B.N., and A.D.N.; Investigation, C.T.D., T.N.T.; Resources, S.-L.W.; Data Curation, C.T.D.; Writing-Original Draft Preparation, S.-L.W and C.T.D.; Writing-Review \& Editing, S.-L.W. and C.T.D.; Visualization, S.-L.W. and C.T.D.; Supervision, S.-L.W.; Project Administration, S.-L.W.; Funding Acquisition, S.-L.W.

Funding: This work was supported in part by a grant from the Ministry of Sciences and Technology, Taiwan (MOST 106-2320-B-032-001-MY3).

Conflicts of Interest: The authors declare no conflict of interest.

\section{References}

1. Azuma, K.; Osaki, T.; Minami, S.; Okamoto, Y. Anticancer and anti-inflammatory properties of chitin and chitosan oligosaccharides. J. Funct. Biomater. 2015, 6, 33-49. [CrossRef] [PubMed]

2. Liang, T.W.; Chen, W.T.; Lin, Z.H.; Kuo, Y.H.; Nguyen, A.D.; Pan, P.S.; Wang, S.L. An amphiprotic novel chitosanase from Bacillus mycoides and its application in the production of chitooligomers with their antioxidant and anti-inflammatory evaluation. Int. J. Mol. Sci. 2017, 17, 1302. [CrossRef] [PubMed]

3. Liang, T.W.; Chen, Y.J.; Yen, Y.H.; Wang, S.L. The antitumor activity of the hydrolysates of chitinous materials hydrolyzed by crude enzyme from Bacillus amyloliquefaciens V656. Process Biochem. 2007, 42, 527-534. [CrossRef]

4. Sun, T.; Qin, Y.; Xu, H.; Xie, J.; Hu, D.; Xue, B.; Hua, X. Antibacterial activities and preservative effect of chitosan oligosaccharide Maillard reaction products on Penaeus vannamei. Int. J. Biol. Macromol. 2017, 105, 764-768. [CrossRef] [PubMed]

5. $\quad$ Liang, T.W.; Liu, C.P.; Wu, C.; Wang, S.L. Applied development of crude enzyme from Bacillus cereus in prebiotics and microbial community changes in soil. Carbohydr. Polym. 2013, 92, 2141-2148. [CrossRef] [PubMed]

6. Lee, H.W.; Park, Y.S.; Jung, J.S.; Shin, W.S. Chitosan oligosaccharides, dp 2-8, have prebiotic effect on the Bifidobacterium bifidium and Lactobacillus sp. Anaerobe 2002, 8, 319-324. [CrossRef]

7. Liang, T.W.; Chen, Y.Y.; Pan, P.S.; Wang, S.L. Purification of chitinase/chitosanase from Bacillus cereus and discovery of an enzyme inhibitor. Int. J. Biol. Macromol. 2014, 63, 8-14. [CrossRef] [PubMed]

8. Liang, T.W.; Lo, B.C.; Wang, S.L. Chitinolytic bacteria-assisted conversion of squid pen and its effect on dyes and adsorption. Mar. Drugs 2015, 13, 4576-4593. [CrossRef] [PubMed]

9. Wang, C.L.; Su, J.W.; Liang, T.W.; Nguyen, A.D.; Wang, S.L. Production, purification and characterization of a chitosanase from Bacillus cereus. Res. Chem. Intermed. 2014, 40, 2237-2248. [CrossRef]

10. Wang, S.L.; Wu, P.C.; Liang, T.W. Utilization of squid pen for the efficient production of chitosanase and antioxidants through prolonged autoclave treatment. Carbohydr. Res. 2009, 244, 979-984. [CrossRef] [PubMed]

11. Liang, T.W.; Jen, S.N.; Nguyen, A.D.; Wang, S.L. Application of chitinous materials in production and purification of a poly (L-lactic acid) depolymerase from Pseudomonas tamsuii TKU015. Polymers 2016, 8, 98. [CrossRef]

12. Wang, S.L.; Chen, S.J.; Liang, T.W.; Lin, Y.D. A novel nattokinase produced by Pseudomonas sp. TKU015 using shrimp shells as substrate. Process Biochem. 2009, 44, 70-76. [CrossRef]

13. Wang, S.L.; Hsu, W.H.; Liang, T.W. Conversion of squid pen by Pseudomonas aeruginosa K-187 fermentation for the production of $N$-acetyl chitooligosaccharides and biofertilizers. Carbohydr. Res. 2010, 345, 880-885. [CrossRef] [PubMed]

14. Kuo, Y.H.; Liang, T.W.; Liu, K.C.; Hsu, Y.W.; Hsu, H.; Wang, S.L. Isolation and identification of a novel antioxidant with antitumor activity from Serratia ureilytica using squid pen as fermentation substrate. Mar. Biotechnol. 2011, 13, 451-461. [CrossRef] [PubMed]

15. Wang, S.L.; Wang, C.Y.; Yen, Y.H.; Liang, T.W.; Chen, S.Y.; Chen, C.H. Enhanced production of insecticidal prodigiosin from Serratia marcescens TKU011 in media containing squid pen. Process Biochem. 2012, 47, 1684-1690. [CrossRef] 
16. Liang, T.W.; Wu, C.C.; Cheng, W.T.; Chen, Y.C.; Wang, C.L.; Wang, I.L.; Wang, S.L. Exopolysaccharides and antimicrobial biosurfactants produced by Paenibacillus macerans TKU029. Appl. Biochem. Biotechnol. 2014, 172, 933-950. [CrossRef] [PubMed]

17. Liang, T.W.; Tseng, S.C.; Wang, S.L. Production and characterization of antioxidant properties of exopolysaccharides from Paenibacillus mucilaginosus TKU032. Mar. Drugs 2016, 14, 40. [CrossRef] [PubMed]

18. Liang, T.W.; Wang, S.L. Recent advances in exopolysaccharides from Paenibacillus spp.: Production, isolation, structure, and bioactivities. Mar. Drugs 2015, 13, 1847-1863. [CrossRef] [PubMed]

19. Nguyen, V.B.; Nguyen, A.D.; Wang, S.L. Utilization of fishery processing by product squid pens for Paenibacillus sp. fermentation on producing potent $\alpha$-glucosidase inhibitors. Mar. Drugs 2017, 15, 274. [CrossRef] [PubMed]

20. Nguyen, V.B.; Wang, S.L. Reclamation of marine chitinous materials for the production of $\alpha$-glucosidase inhibitors via microbial conversion. Mar. Drugs 2017, 15, 350. [CrossRef] [PubMed]

21. Wang, S.L.; Li, H.T.; Zhang, L.J.; Lin, Z.H.; Kuo, Y.H. Conversion of squid pen to homogentisic acid via Paenibacillus sp. TKU036 and the antioxidant and anti-inflammatory activities of homogentisic acid. Mar. Drugs 2016, 14, 183. [CrossRef] [PubMed]

22. Doan, C.T.; Tran, T.N.; Nguyen, V.B.; Nguyen, A.D.; Wang, S.L. Conversion of squid pens to chitosanases and proteases via Paenibacillus sp. TKU042. Mar. Drugs 2018, 16, 83. [CrossRef] [PubMed]

23. Loni, P.P.; Patil, J.U.; Phugare, S.S.; Bajekal, S.S. Purification and characterization of alkaline chitinase from Paenibacillus pasadenensis NCIM 5434. J. Basic Microbiol. 2014, 54, 1080-1089. [CrossRef] [PubMed]

24. Zitouni, M.; Fortin, M.; Scheerle, R.K.; Letzel, T.; Matteau, D.; Rodrigue, S.; Brzezinski, R. Biochemical and molecular characterization of a thermostable chitosanase produced by the strain Paenibacillus sp. 1794 newly isolated from compost. Appl. Microbiol. Biotechnol. 2013, 97, 5801-5813. [CrossRef] [PubMed]

25. Ueda, J.; Kurosawa, N. Characterization of an extracellular thermophilic chitinase from Paenibacillus thermoaerophilus strain TC22-2b isolated from compost. World J. Microbiol. Biotechnol. 2015, 31, 135-143. [CrossRef] [PubMed]

26. Garcia-Gonzalez, E.; Poppinga, L.; Fünfhaus, A.; Hertlein, G.; Hedtke, K.; Jakubowska, A.; Genersch, E. Paenibacillus larvae chitin-degrading protein PlCBP49 is a key virulence factor in American foulbrood of honey bees. PLoS Pathogen. 2014, 10, e1004284. [CrossRef] [PubMed]

27. Singh, A.K.; Chhatpar, H.S. Purification and characterization of chitinase from Paenibacillus sp. D1. Appl. Biochem. Biotechnol. 2011, 164, 77-88. [CrossRef] [PubMed]

28. Fu, X.; Yan, Q.; Wang, J.; Yang, S.; Jiang, Z. Purification and biochemical characterization of novel acidic chitinase from Paenibacillus barengoltzii. Int. J. Biol. Macromol. 2016, 91, 973-979. [CrossRef] [PubMed]

29. Kim, Y.H.; Park, S.K.; Hur, J.Y.; Kim, Y.C. Purification and characterization of a major extracellular chitinase from a biocontrol bacterium, Paenibacillus elgii HOA73. Plant Pathol. J. 2017, 33, 318-328. [CrossRef] [PubMed]

30. Guo, X.; Xu, P.; Zong, M.; Lou, W. Purification and characterization of alkaline chitinase from Paenibacillus pasadenensis CS0611. Chin. J. Catalys. 2017, 38, 665-672. [CrossRef]

31. Kimoto, H.; Kusaoke, H.; Yamamoto, I.; Fujii, Y.; Onodera, T.; Taketo, A. Biochemical and genetic properties of Paenibacillus glycosyl hydrolase having chitosanase activity and discoidin domain. J. Biol. Chem. 2002, 277, 14695-14702. [CrossRef] [PubMed]

32. Itoh, T.; Sugimoto, I.; Hibi, T.; Suzuki, F.; Matsuo, K.; Fujii, Y.; Taketo, A.; Kimoto, H. Overexpression, purification, and characterization of Paenibacillus cell surface-expressed chitinase ChiW with two catalytic domains. Biosci. Biotechnol. Biochem. 2014, 78, 624-634. [CrossRef] [PubMed]

33. Jung, W.J.; Kuk, J.K.; Kim, K.Y.; Kim, T.H.; Park, R.D. Purification and characterization of chitinase from Paenibacillus illinoisensis KJA-424. J. Microbiol. Biotechnol. 2005, 15, 274-280.

34. Meena, S.; Gothwal, R.K.; Saxena, J.; Nehra, S.; Mohan, M.K.; Ghosh, P. Effect of metal ions and chemical compounds on chitinase produced by a newly isolated thermotolerant Paenibacillus sp. BISR-047 and its shelf-life. Int. J. Curr. Microbiol. Appl. Sci. 2015, 4, 872-881.

35. Wang, S.L.; Liu, C.P.; Liang, T.W. Fermented and enzymatic production of chitin/chitosan oligosaccharides by extracellular chitinases from Bacillus cereus TKU027. Carbohydr. Polym. 2012, 90, 1305-1313. [CrossRef] [PubMed] 
36. Nguyen, A.D.; Huang, C.C.; Liang, T.W.; Nguyen, V.B.; Pan, P.S.; Wang, S.L. Production and purification of a fungal chitosanase and chitooligomers from Penicillium janthinellum D4 and discovery of the enzyme activators. Carbohydr. Polym. 2014, 108, 331-337. [CrossRef] [PubMed]

37. Yoon, H.G.; Kim, H.Y.; Kim, H.K.; Kim, K.H.; Hwang, H.J.; Cho, H.Y. Cloning and expression of thermostable chitosanase gene from Bacillus sp. KFB-C108. J. Microbiol. Biotechnol. 1999, 9, 631-636.

38. Liang, T.W.; Hsieh, J.L.; Wang, S.L. Production and purification of a protease, a chitosanase, and chitin oligosaccharides by Bacillus cereus TKU022 fermentation. Carbohydr. Res. 2012, 362, 38-46. [CrossRef] [PubMed]

(C) 2018 by the authors. Licensee MDPI, Basel, Switzerland. This article is an open access article distributed under the terms and conditions of the Creative Commons Attribution (CC BY) license (http://creativecommons.org/licenses/by/4.0/). 